Published in "OPSEARCH", 2020, vol. 57, no. 3, pp. 765-786, which should be

cited to refer to this work. DOI: 10.1007/s12597-020-00442-z

\title{
Identification and Ranking of Key Factors Impacting Efficiency of Indian Shipping Logistics Sector
}

\section{Dhirendra Prajapati ${ }^{1}$, Yash Daultani ${ }^{2}$, Naoufel Cheikhrouhou ${ }^{3}$, Saurabh Pratap ${ }^{1^{*}}$}

${ }^{1}$ Department of Mechanical Engineering, Indian Institute of Information Technology, Design \& Manufacturing, Jabalpur, India

${ }^{2}$ Department of Operations Management, Indian Institute of Management, Lucknow, India

${ }^{3}$ Geneva School of Business Administration, HES-SO, University of Applied Sciences Western Switzerland, Geneva, Switzerland

*Corresponding Author: Saurabh Pratap, Email id: s.pratapiitkgp@gmail.com

Orcid Id: https://orcid.org/0000-0002-2579-7859

\begin{abstract}
Shipping logistics is one of the very important criteria which can directly and indirectly affect the economy and GDP of any country. Shipping logistics depends on various factors which have been addressed by several authors in their previous studies. Studies in this literature are focused on selecting the most impactful factors among all the criteria. Methods used in this literature are fuzzy AHP (Analytical Hierarchy Process) and fuzzy TOPSIS (Technique for order of Preference by Similarity to Ideal Solution) for multi-criteria decision analysis. These methods also helped in this literature to develop a new hybrid method "fuzzy TOPSIS AHP”. There have been no studies involving maritime logistics with comparative analysis of multi-criteria decision making i.e., fuzzy AHP and fuzzy TOPSIS AHP. The literature involved large number of expert opinions on the factor prioritization of maritime logistics. Factors selected for prioritization are Environmental Sustainability, Supply and Demand, Operations and Port Selection. However, the research showed that the comparative analysis of the results was quite opposite to one another and proposed a new way for researchers to use the hybrid method of fuzzy TOPSIS AHP method in future research. The study aimed to improve the existing maritime model which can help professionals to get connected with the maritime logistics firms. The study also aims to contribute this model for researchers in their study related to maritime logistics.
\end{abstract}

Keywords: Shipping logistics, multi-criteria decision making, Fuzzy TOPSIS AHP, Port Selection, Environment Sustainability 


\title{
Identification and Ranking of Key Factors Impacting Efficiency of Indian Shipping Logistics Sector
}

\begin{abstract}
Shipping logistics is one of the crucial sectors that affect the economy and GDP of a country, both directly and indirectly. Shipping logistics depends on various factors such as adequate infrastructure, port efficiency, frequency of ship visits, geographical locations, quick response to port users, port charges, and ports reputations for cargo damage. The focus of this paper is to identify the most impactful factors out of four key factors; the environmental sustainability, supply and demand, operations, and port selection with the help of multi-criteria decision-making (MCDM) techniques. For this purpose, the Fuzzy Analytical Hierarchy Process (AHP) and a newly proposed hybrid method, i.e., "Fuzzy Technique for Order of Preference by Similarity to Ideal Solution (TOPSIS) AHP" are utilized. This work involved a large number of expert opinions on the ranking and prioritization of different factors in maritime logistics. A comparative analysis of results obtained from the fuzzy AHP method and the Fuzzy TOPSIS-AHP method is presented.
\end{abstract}

Keywords: Shipping logistics, multi-criteria decision making, Fuzzy TOPSIS-AHP, Port Selection, Environmental Sustainability

\section{Introduction}

Since transportation has developed in recent decades, the dependency on waterways has increased tremendously. Moreover, transportation is now considered as one of the four pillars of globalization, along with communications, international standardization, and trade liberalization (Hoffmann \& Change, 2014). International trade is majorly dependent on shipping, as two-third of the world prefers maritime transport (Corbett \& Winebrake, 2008). Airlines are trying hard to cover all the ship routes, but they are still considered as a substitute in case of light cargo or high valued items requiring faster transportation.

A process of port selection requires many relevant and important criteria (Sayareh \& Alizmini, 2014). There was a sustained and strong economic growth of India between $1990-2010$ when the export sector became prominent regionally as well as globally. The existing port operations and the progress of new ports have taken a sharper path in the last era (Venkita 
Subramanian \& Thill, 2019). In most of the previous studies, environmental issues are either ignored or taken as secondary importance (Psaraftis, 2016). For the port industry, environmental sustainability is of rising concern for policymakers, port authorities, local communities, and port users (Acciaro et al., 2014a).

According to a report of the Government of India, the percentage of India's maritime transportation in world trade is $8 \%$, and share of waterways in terms of volume in Indians logistics is $6 \%$ as compared to road, rails, and pipelines ${ }^{1}$. The investment in the shipping industry is $32.5 \%$, i.e., Rs 3.03 lakh crore (Niti Aayog India, https://niti.gov.in/). India consists of 12 major ports and 187 non-major ports ${ }^{1}$. Cargo traffic was recorded at 1.052 million metric tonnes (MMT) in the year 2015 (Trishala, 2016). In February 2019, all ports handled about 633.87 million tonnes of cargo starting from April 2018 ${ }^{1}$. The coastline of India is spreading more than 7517 kilometers long $^{1}$. Cargo ships of America, East Asia, and Africa pass through Indian territorial waters. Investment attracted by Indian ports by 2020 is expected to reach US $\$ 43.03$ Billion ${ }^{1}$. The Indian government's policy of 100 percent FDI (Foreign Direct Investment) has also led to the tax holiday for foreign investors. The National Maritime Development Program is initiated to develop the marine sector with the planned budget is US\$11.8 Billion ${ }^{1}$. Also, the Indian government has major plans to create port facilities of around 3,200 million metric tonnes (MMT) to entertain the expected traffic of 2,500 MMT by the year 2020 (Ministry of Shipping India, http://sagarmala.gov.in/).

As the transportation business is growing day by day, it is necessary for the logistics department to manage the flow of things in a better and more efficient way. Therefore, this study aims to determine the crucial factors related to efficient shipping logistics, which plays a major role in it. In this study, we have focused on the four major factors such as environmental sustainability, supply and demand, operations, and port selection in order to make the best possible decision for selecting the impactful factors in the efficient shipping logistics. This article is trying to suggest proper strategies by looking into many kinds of factors and improving the shipping logistics systems in order to make it more efficient. MCDM techniques such as fuzzy AHP, and a newly proposed hybrid Fuzzy TOPSIS-AHP methods are used for ranking and prioritization of factors.

[1-Source: Ministry of Shipping - GOI, Care Ratings, Indian Ports Association, https://www.ibef.org/download/ports-mar-2019.pdf] 
The rest of the paper is arranged as follows. Section 2 contains the previous literature. The problem description is given in section 3. In section 4 , we have discussed the multi-criteriadecision-making techniques. Sections 5 is related to the results and discussion. Section 6 concludes the work.

\section{Literature Review}

In this section, we have reviewed the previous literature based on the considered problem for a better understanding of maritime transportations and logistics. The literature is divided into different subsections that are environmental sustainability, supply and demand, port operations, port selection, shipping logistics, and solution approach.

\subsection{Environmental Sustainability}

Acciaro et al. (2014b) compiled and analyzed the growing concerns for port decision-makers, policy managers, port customers, and the local population. They investigated some innovations on the sustainability of seaports. They also tried to develop a method of measuring the level of success of innovations with respect to the array of definite objects. They considered several factors such as adaptation to climate change, optimized use of space, and waste reception facility for the study. Their work provided two main results; the innovation's success ranking and a ranking summarizing the significance associated with policy action with a set of clearly distinct goals. Psaraftis (2016) focused on the environmental issues on maritime emissions and objectives that may involve various win-win solutions and trade-offs that are typically desired. Rødseth, et al. (2018), studied about the time spent by ships in port and associated anthropogenic gas emissions in the environment.

\subsection{Supply and Demand}

Jugović et al. (2015) investigated how the relationship between demand and supply affects market price. They developed relationships between variables, which affect both supply and demand. Also, they tried to answer some questions like, what affects freight on the shipping markets or if the average profit is according to their need or if they can pay off the new ship with average in their profit books. The variables such as world economy, transport costs, merchant fleet, and political events were focused in their research. Ducruet \& Lugo (2013) contributed to updating the networks 
of shipping logistics and considered some important factors like economics, the system of cities, the geography of transport, etc. Daultani et al. (2019) hypothesized that operations in any form are depend upon inputs from other functional departments and cause different risks for the company. Le et al. (2019) reviewed the recent practice, empirical case studies, and academic research based on three major pillars of demand, supply, and management and operations. They have given various avenues for promising fields of applications, such as management and operations, as well as improving societal and behavioral impacts to allow and form a crowd-shipping system, i.e., sustainable, integrated, and dynamic.

\subsection{Port Operations}

The term operations in this paper is regarded as steps taken by port representatives and ship members to minimize cost and maximize profit at the same time. There are three variables for port operations, which affect the costs at the high levels. These three variables are berth scheduling, cargo prioritization, and terminal and crane allocation. Kim \& Moon (2003) extended the confidence in finding out berthing times and spot of containerships in port workstations. They developed a mixed-integer-linear-programming (MILP) model for berth scheduling problems. Their objective function consists of two parts. First, the cost that resulted due to non-optimal berthing locations and the penalty cost resulting from interruptions in the departure of vessels from the harbor. Zeng et al. (2017) developed an integrated model in order to optimize the plan of direct transshipment, the assignment of storage space, and berth allocation, simultaneously. They focused on to minimize the vessels' delay costs and the operational costs of yard cranes and trucks.

Tong \& Nachtmann (2017) aimed to reduce cargo value deficit and response time while employing a minimum distance approach. It considered factors like terminal volume and barge characteristics in a quantified manner. Their mathematical model formulated a non-linear integer program (NLIP). Their approach is towards the realistic scenario of Mississippi River disruption where cargo offload is prioritized according to their properties like hazardous, non-hazardous, valuable and small lifetime or freshness. With regard to crane allocation, Ursavas (2017) imparted their knowledge to reduce the concerns of terminal operators. They developed a decision support system (DSS) for finding the underlying cause of complex crane scheduling problems. Their case study is based on practicing real ship data at the Izmir container terminal in Turkey. Their main aim was to draw attention to the bottleneck problems of real-life function in a container terminal. 
Some of the researchers attempted to resolve this issue with time by using heuristics approach (Daganzo, 1989). Pratap et al. (2015) studied important factors related to crane allocation and formulated a model to minimize the crane allocation time and total operational time.

\subsection{Port Selection}

Subramanian \& Thill (2019) presented several insights regarding the privatization of Indian ports which are changing the market share of containerized transports across two important trade corridors of India. They have studied the effects of inland infrastructural development and privatization on the dynamics of Indian port selection. Ugboma et al. (2006) proposed a survey to determine various factors that shippers consider while selecting a port and the way they are prioritized according to their impact. Investigations of decision factors were also done by McGinnis (1979) and D'este \& Meyrick (1992). They recognized three categories of factors, i.e., route factors, cost factors, and service factors. Seo et al. (2018) aimed to estimate the complete performance and rank the firms' ship management by implementing an integrated model of fuzzy TOPSIS and AHP to help the critical decision making for selection of SMF. Sayareh \& Alizmini (2014) mainly focused on the factors of decisive port selection and weights of the most leading decision-making criteria with the help of the TOPSIS method and optimized the seaport container by using the AHP method. Pratap et al. (2018) presented an integrated modeling framework for bulk handling port operations.

\subsection{Shipping Logistics}

Ducruet \& Lugo (2013) focused on the network renewal analysis based on the complex systems in the shipping logistics. They studied the regularly described networks and flows on the level of terminals and organizations rather than cities. Pham et al. (2019) worked on improving supply chain performance. A model of information sharing in Vietnamese shipping logistics was developed which was irrespective of the reluctant attitude of the companies involved in logistics work. They tried to improve the economy of Vietnam with the help of their findings. Pratap et al. (2019) investigated the ship routing and scheduling problem to minimize the total transportation distance to reduce fuel consumption. 


\subsection{Solution Approach}

Sayareh \& Alizmini (2014) focused to balance the utmost dominant decision-making-criteria by TOPSIS and the optimized container seaport selection by the AHP method according to the significant factors of port selection. Meena et al. (2019) used AHP and fuzzy AHP to rank the identified SWOT factors in the agro-food supply chain in the Indian context. Ugboma et al. (2006) used the analytical hierarchy process (AHP) method to form a better framework. They considered several factors for their study such as port efficiency, adequate infrastructure, frequency of ship visits, quick response to port users, geographical locations, port charges, and ports reputations for cargo damage. They found out the significant methods for port managers, which help to recognize the strength and limitations of the ports. For more approached in the broader context, readers may see several papers such as Mogale et al. (2018), Mogale et al. (2019a), Mogale et al. (2019b), De et al. (2019), Gupta et al. (2019), Singh et al. (2020).

\subsection{Research Motivation}

Most of the researchers have focused on the port and vessel selections in their study. However, shipping logistics needs to be properly managed to make it efficient on a larger scale. The literature review emphasizes that the recent scenario of Indian shipping logistics is highly unorganized; there is a lack of proper port selection, port operations, ship scheduling, product wastage, and lack of transportation network, etc. The overall performance of shipping logistics in India is very poor, which affects the Indian economy. Hence, it is necessary to do a strategic analysis of the Indian shipping logistics in order to achieve more efficient logistics. To address the above-identified issues, this paper considers all factors like sustainability, demand, and supply, etc. in a shipping logistics system in an integrated manner.

\section{Problem Description}

The growing economies around the world are setting an example and creating challenges for Indian maritime transport. Cost, efficiency, sustainability, and safety are some of the factors on which the Indian industries are lagging behind. According to the shipping ministry of India, this is resulting in increased product rates that account for almost 30\% to 35\% of the cost of production. Time is also a major factor, which governs the inventory costs and contributes towards high commodity costs. Dependencies on modes of transportation, which are responsible for high carbon content in 
the environment and safety as rail, and road transportation are more prone to accidents. The old structure of managing shipping logistics is responsible for the situations mentioned above. In this study, we are focusing to reduce the problems in the Indian maritime industry and emphasizing on meeting the demanding business requirements and taking care of the environment at the same time. To accomplish the motive of the study, we have to determine, analyze, rank and prioritize the existing factors with the help of MCDM methods such as the fuzzy AHP method and the proposed hybrid fuzzy TOPSIS-AHP method. The factors which we have taken into consideration in this study are port efficiency, adequate infrastructure, frequency of ship visits, quick response to port users, geographical locations, port charges, and ports reputations for cargo damage. Figure 1 describes major factors and their sub-factors, which play an important role in shipping logistics. Operational definitions and literature support of these factors and their sub-factors are given in Table I.

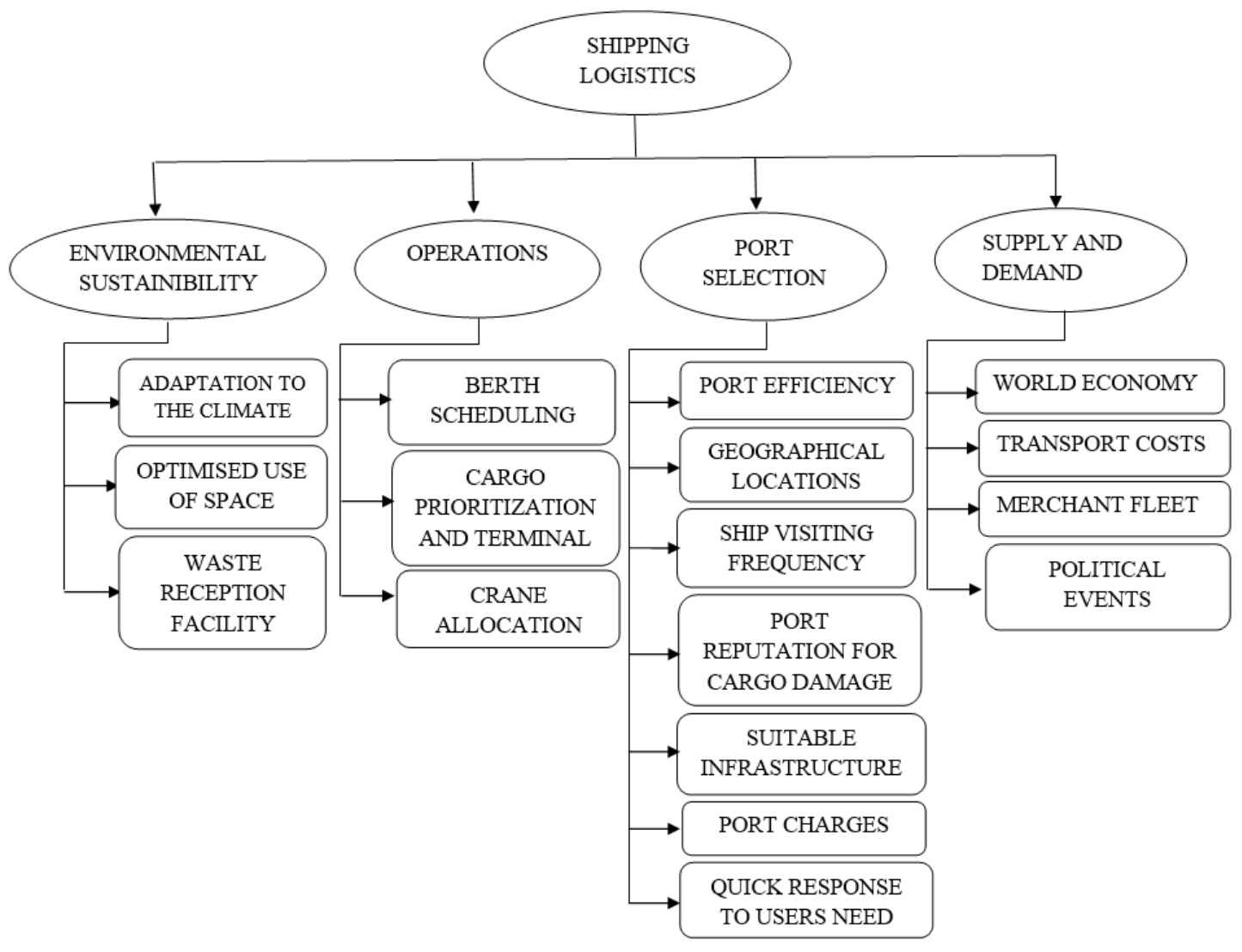

Figure 1: Factors and sub-factors affecting shipping logistics 
Table I: Operational definitions of shipping logistics factors and sub-factors

\begin{tabular}{|c|c|c|c|c|}
\hline $\begin{array}{l}\text { Sr. } \\
\text { No. }\end{array}$ & Main variable & Sub-variable & Operational definitions & Sources \\
\hline \multirow{3}{*}{1.} & \multirow{3}{*}{$\begin{array}{l}\text { Environmental } \\
\text { sustainability }\end{array}$} & $\begin{array}{l}\text { Adaptation to climate } \\
\text { change }\end{array}$ & $\begin{array}{l}\text { Actions to be taken with induced effect } \\
\text { of climate change. }\end{array}$ & (Acciaro et al., 2014b) \\
\hline & & Optimized use of space & $\begin{array}{l}\text { Avoiding unnecessary usage of space } \\
\text { promoting better planning. }\end{array}$ & (Acciaro et al., 2014b) \\
\hline & & Waste reception facility & $\begin{array}{l}\text { Promoting waste management and waste } \\
\text { recycling methods. }\end{array}$ & (Acciaro et al., 2014b) \\
\hline \multirow{4}{*}{2.} & \multirow{4}{*}{$\begin{array}{l}\text { Supply and } \\
\text { demand }\end{array}$} & World economics & $\begin{array}{l}\text { International exchange of goods and } \\
\text { services which is dependent on shipping } \\
\text { for about } 90 \% \text {. }\end{array}$ & (Jugović et al., 2015) \\
\hline & & Transport costs & $\begin{array}{l}\text { Cost to be paid in monetary terms for } \\
\text { carrying goods from one distant place to } \\
\text { another. }\end{array}$ & (Jugović et al., 2015) \\
\hline & & Merchant fleet & $\begin{array}{c}\text { Group of civilian ships carrying } \\
\text { passengers or cargo }\end{array}$ & (Jugović et al., 2015) \\
\hline & & Political events & $\begin{array}{l}\text { Refers to strikes, revolutions and } \\
\text { changes due to government policies. }\end{array}$ & (Jugović et al., 2015) \\
\hline \multirow{3}{*}{3.} & \multirow{3}{*}{ Operations } & Berth scheduling & $\begin{array}{l}\text { To determine time of berthing and } \\
\text { positions of naval vessels. }\end{array}$ & (Kim \& Moon, 2003) \\
\hline & & Cargo prioritization & $\begin{array}{l}\text { To arrange cargo in order of their } \\
\text { importance and other several factors to } \\
\text { incur minimum loss. }\end{array}$ & $\begin{array}{l}\text { (Tong \& Nachtmann, } \\
\text { 2017) }\end{array}$ \\
\hline & & Crane allocation & $\begin{array}{l}\text { Allotting suitable crane for required } \\
\text { ships according to rate, positions and } \\
\text { another factor. }\end{array}$ & (Ursavas, 2017) \\
\hline \multirow{5}{*}{4.} & \multirow{5}{*}{ Port selection } & $\begin{array}{c}\text { Port efficiency } \\
\text { Geographical locations }\end{array}$ & $\begin{array}{l}\text { The efficiency of port to perform work } \\
\text { with respect to other ports. } \\
\text { Locations which are easily accessible as } \\
\text { compared to other ports. }\end{array}$ & $\begin{array}{l}\text { (Ugboma et al., 2006) } \\
\text { (Ugboma et al., 2006) }\end{array}$ \\
\hline & & Ship visiting frequency & $\begin{array}{c}\text { The number of ships or vessels visiting } \\
\text { per unit time for a port. }\end{array}$ & (Ugboma et al., 2006) \\
\hline & & $\begin{array}{l}\text { Port reputation for cargo } \\
\text { damage }\end{array}$ & $\begin{array}{c}\text { The image of a port in keeping its goods } \\
\text { and cargo in a good shape in case of a } \\
\text { stoppage. }\end{array}$ & (Ugboma et al., 2006) \\
\hline & & Suitable infrastructure & $\begin{array}{l}\text { Infrastructure which can handle the } \\
\text { heavy ship traffic and other activities of } \\
\text { ports. }\end{array}$ & (Ugboma et al., 2006) \\
\hline & & Port charges & $\begin{array}{l}\text { The amount of money payable to the } \\
\text { port for its services. }\end{array}$ & (Ugboma et al., 2006) \\
\hline
\end{tabular}




\section{Solution Methodology}

The considered factors are ranked and prioritized with the help of multi-criteria decision-making methods. For factor ranking and prioritization, first, we have developed the questionnaire on the basis of all factors. These questionnaires are distributed in the form of survey forms. Questionnaires are filled by industry persons and academicians. This data is used as an input to calculate the rankings with the help of fuzzy AHP and proposed fuzzy TOPSIS-AHP methods. Fuzzy TOPSIS-AHP method is a hybrid method developed by combining two MCDM methods; fuzzy AHP method and TOPSIS method. A series of questionnaire is developed with an aim to compare them pair-wise and prioritize them according to their expertise. Tables II and III summarize this information.

Table II: Representative Questionnaire

\begin{tabular}{cl}
\hline Sr. No. & Questionnaire on main factors of shipping logistics \\
\hline 1 & $\begin{array}{l}\text { How much do you agree with the importance of environmental sustainability over } \\
\text { supply and demand? }\end{array}$ \\
\hline 2 & $\begin{array}{l}\text { How much do you agree with the importance of environmental sustainability over } \\
\text { operations? }\end{array}$ \\
\hline 3 & $\begin{array}{l}\text { How much do you agree with the importance of environmental sustainability over } \\
\text { port selection? }\end{array}$ \\
\hline 4 & $\begin{array}{l}\text { How much do you agree with the importance of supply and demand over } \\
\text { operations? }\end{array}$ \\
\hline 6 & $\begin{array}{l}\text { How much do you agree with the importance of supply and demand over the } \\
\text { selection of ports? }\end{array}$ \\
\hline
\end{tabular}

Table III: Options and Interpretations

\begin{tabular}{cll}
\hline Sr. No. & Options & Interpretation \\
\hline 1 & Strongly agree & Judgment strongly favors one criterion over another. \\
\hline 2 & Moderately agree & Judgment slightly favor one criterion over another \\
\hline 3 & Equally important & Two criteria contribute in the same way to the object \\
\hline 4 & Moderately disagree & A criterion is somewhat inferior to another \\
\hline 5 & Strongly disagree & A criterion is strongly inferior to another \\
\hline
\end{tabular}




\subsection{Fuzzy AHP (Geometric Mean Method)}

The fuzzy AHP is a strong and sophisticated tool to make decisions, which involves conflicting benchmarks in decision-making. It involves the concepts of fuzzy logic and analytical hierarchy. Saaty (1990) proposed the AHP method and described how to structure a decision problem. AHP method sorts different objectives, factors, and sub-factors into a multi-level hierarchy. The input gathering for using the AHP method is quite easy. AHP starts with a pairwise comparison of different factors or alternatives, which affect the decision-making criterion. These pairwise comparisons can be done with the input of experts in the respective field. This input from the survey of experts according to their experiences, opinions, and bias are essential, as they will lead to prioritizing the factors. Because it involves not one or two but many experts, so arithmetic mean of their inputs for every specific comparison is to be taken to form the pair-wise matrix. For example: If there are 100 experts for comparing the importance of "factor 1" and "factor 2". The options available to choose for prioritizing the factors are given below in table IV.

Table IV: Options available for experts

\begin{tabular}{c}
\hline Strongly agree \\
Moderately agree \\
Equally important \\
Moderately disagree \\
Strongly disagree \\
\hline
\end{tabular}

So, the maximum percentage of experts that will select the option will be considered as an input for the AHP method, after that the fuzzy logic comes into play. The input obtained from the experts is to be converted into processable data, which is done with the help of numbers that denotes the intensity of impact. So, if "factor 1" is dominant over "factor 2" or maybe it can be equally important then a specific number given according to the importance over another. This will lead the result to a more precise conclusion. Saaty (1990), proposed a fundamental scale as given in Table V.

Table V: Intensity of importance and their explanation

\begin{tabular}{ccc}
\hline $\begin{array}{c}\text { Intensity of } \\
\text { importance }\end{array}$ & Explanation & $\begin{array}{c}\text { Fuzzy } \\
\text { number }\end{array}$ \\
\hline 1 & Factor of equal importance & $(1,1,1)$ \\
\hline 3 & Slightly favoring the factor over the other & $(2,3,4)$ \\
\hline
\end{tabular}




\begin{tabular}{ccc}
\hline 5 & Strongly favoring the factor over the other & $(4,5,6)$ \\
\hline 7 & Very strongly favoring the factor over the other & $(6,7,8)$ \\
\hline 9 & Absolutely favoring with highest degree of assertion & $(9,9,9)$ \\
\hline
\end{tabular}

Now, the fuzzy AHP will be implemented in the following steps:

A pair-wise comparison matrix ' $A_{i j}$ ' is developed for ' $n$ ' number of factors with one another and $a_{i j}$ is the intensity of importance in the matrix where $i \in\{1,2 \ldots n\} \& j \in\{1,2 \ldots n\}$. Since row and columns consist of the same factors comparison so if the intensity of importance of factor 1 with respect to factor 2 is $a_{i j}$ then the intensity of importance for factor 2 with respect to factor 1 is $a_{j i}=1 / a_{i j}$.

$$
\begin{gathered}
A_{i j}=\left[\begin{array}{ccccc}
1 & a_{12} & a_{13} & \cdots & a_{1 n} \\
a_{21} & 1 & a_{23} & \cdots & a_{2 n} \\
a_{31} & a_{32} & 1 & \cdots & a_{3 n} \\
\vdots & \vdots & \vdots & \ddots & \vdots \\
a_{n 1} & a_{n 2} & a_{n 3} & \cdots & 1
\end{array}\right]=\left[\begin{array}{ccccc}
1 & a_{12} & a_{12} & \cdots & a_{1 n} \\
1 / a_{12} & 1 & a_{23} & \ldots & a_{2 n} \\
1 / a_{13} & 1 / a_{23} & 1 & \ldots & a_{3 n} \\
\vdots & \vdots & \vdots & \ddots & \vdots \\
1 / a_{1 n} & 1 / a_{2 n} & 1 / a_{3 n} & \cdots & 1
\end{array}\right] \\
a_{i j} \in\left\{\begin{array}{c}
1 / 9,1 / 8,1 / 7,1 / 6,1 / 5,1 / 4,1 / 3,1 / 2,2,3,4,5,6,7,8,9, i \neq j \\
1, i=j
\end{array}\right.
\end{gathered}
$$

This is the scale that is used to convert the survey form input into fuzzy numbers.

$$
A_{i j}=\left\{\begin{array}{ll}
1, & A_{i j}=0 \% \\
3, & A_{i j} \geq 20 \% \\
5, & A_{i j} \geq 40 \% \\
7, & A_{i j} \geq 60 \% \\
9, & A_{i j} \geq 80 \%
\end{array} \quad A_{i j}= \begin{cases}\frac{1}{3}, & A_{i j} \geq-20 \% \\
\frac{1}{5}, & A_{i j} \geq-40 \% \\
\frac{1}{7}, & A_{i j} \geq-60 \% \\
\frac{1}{9}, & A_{i j} \geq-80 \%\end{cases}\right.
$$


The next step followed is proposed in Hsieh et al. (2004) for calculating fuzzy weights using the geometric mean method. The geometric mean of the fuzzy number in pairwise comparison matrix is calculated by

$$
r_{i}=\left(a_{i 1} \times \cdots \times a_{i j} \times \cdots a_{i n}\right)^{\frac{1}{n}}
$$

Where $r_{i}$ is the geometric mean of 'factor $i$ ' to other factors. Using the obtained geometric values, fuzzy weights can be calculated. $w_{i}$ is a fuzzy weight of 'factor $i$ ' which can be obtained by

$$
w_{i}=r_{i} \times\left(r_{1}+r_{2}+r_{3}+\cdots+r_{n}\right)^{-1}
$$

These fuzzy weights obtained are $w_{i}=\left(l w_{i}, m w_{i}, u w_{i}\right)$ where $l w_{i}$ is lower fuzzy, $m w_{i}$ is middle fuzzy value and $u w_{i}$ is upper fuzzy value. The fuzzy weight obtained is then defuzzified into a crisp numerical value. The method used for defuzzication is the center of area.

$$
W_{i}=\frac{l w_{i}+m w_{i}+u w_{i}}{3}
$$

The weight of crisp numerical value is obtained and then normalization is carried out with this step

$$
X_{i j}=\frac{W_{i}}{\sum_{i=1}^{n} W_{i}}
$$

Now, these normalized values can be used for a ranking which will show us the dominance of factors over each other.

\subsection{Fuzzy TOPSIS AHP Analysis using Geometric Mean Method}

Chen (2000) proposed a new MCDM method using fuzzy theory called fuzzy TOPSIS. This method is also a vital tool for the decision-making problem under the fuzzy theory. We introduce a scale to assign fuzzy numbers for the application of fuzzy TOPSIS-AHP. This method is constructed as a hybrid of fuzzy AHP (Saaty, 1990) and fuzzy TOPSIS to give fuzzy TOPSISAHP. The Fuzzy TOPSIS-AHP follows the same method of fuzzy TOPSIS. The role of fuzzy AHP comes into play when the weights that are taken from the fuzzy AHP method and will be used as 
input in the fuzzy TOPSIS method, to give a new tool for the scale is as follows. Sirisawat \& Kiatcharoenpol (2018) have shown a similar idea regarding this. Table VI summarizes the proposed scale.

Table VI: Fuzzy numbers and their explanation

\begin{tabular}{cc}
\hline Fuzzy Number & Explanation \\
\hline$(1,1,1)$ & Strongly Disagree/ Very low \\
\hline$(2,3,4)$ & Moderately Disagree/ Low \\
\hline$(4,5,6)$ & Equally Important/ Average \\
\hline$(6,7,8)$ & Moderately Agree/ High \\
\hline$(9,9,9)$ & Strongly Agree/ Very high \\
\hline
\end{tabular}

Since the number of experts involved in decision-making would be in large numbers so according to their inputs, their individual analysis of the comparison of different factors would be different.

For example, there are ' $k$ ' experts then the number of comparison matrix would be ' $k$ ' in number.

Pairwise decision matrix for experts is as shown below.

$$
\left(\begin{array}{ccc}
d_{11} & \ldots & d_{1 n} \\
\vdots & \ddots & \vdots \\
d_{n 1} & \cdots & d_{n n}
\end{array}\right)
$$

In addition, $d_{i j}=\left(e_{i j}, f_{i j}, g_{i j}\right)_{z}$ Where, $d_{i j}$ element of the pairwise decision matrix is $\left(e_{i j}, f_{i j}, g_{i j}\right)$ where, $i \in\{1,2 \ldots n\} \& j \in\{1,2 \ldots n\}$

Combining the entire matrices obtained from the experts' input to form a resultant matrix, which will give us the overall fuzzy numbers for all the factors.

$$
X_{i j}=\left(\begin{array}{ccc}
x_{11} & \cdots & x_{1 n} \\
\vdots & \ddots & \vdots \\
x_{n 1} & \cdots & x_{n n}
\end{array}\right)
$$


$X_{i j}$ is a combined pairwise decision matrix. Where, $x_{i j}=\left(a_{i j}, b_{i j}, c_{i j}\right)$ element of pairwise decision matrix. Calculating the values $x_{i j}$ of which is necessary to move ahead.

The weight of the criteria is to be determined according to the fuzzy scale. Comparing two factors, quantifying their dominance into linguistic terms and then converting them into fuzzy numbers is to be performed as follows.

Here, weight is derived in the fuzzy AHP method (Geometric Mean Method) denoted by w, which is a very important step that distinguishes fuzzy TOPSIS AHP from fuzzy TOPSIS.

The combined decision matrix is also taken the same as used in the fuzzy AHP process. So, the above-mentioned steps of making decision matrix are not required in new derived fuzzy TOPSIS AHP (Geometric mean method).

The normalized fuzzy decision matrix is

$$
\begin{gathered}
M=\left[r_{i j}\right] \\
r_{i j}=\left(\frac{a_{i j}}{c_{i j}^{*}}, \frac{b_{i j}}{c_{i j}^{*}}, \frac{b_{i j}}{c_{i j}^{*}}\right)
\end{gathered}
$$

where $c_{i j}^{+}=\max \left\{c_{i j}\right\}$

$$
u_{i j}=r_{i j} \times w_{i}
$$

where $a_{i j}^{-}=\max \left\{a_{i j}\right\}$

Where $M$ is a fuzzy matrix of element $r_{i j}$ which consists of both cost criteria and benefit criteria. The weighted normalized matrix can be calculated by calculating $u_{i j}$, which is given by

$$
u_{i j}=r_{i j} \times w_{i}
$$

The next step is to calculate fuzzy positive ideal solution (FPIS) and fuzzy negative ideal solution (FNIS) respectively. 


$$
\begin{aligned}
& A^{+}=\left(u_{1}^{+}, u_{2}^{+}, \ldots, u_{n}^{+}\right) \text {where, } u_{j}^{+}=\max \left\{u_{i j 3}\right\} \\
& A^{-}=\left(u_{1}^{-}, u_{2}^{-}, \ldots, u_{n}^{-}\right) \text {where, } u_{j}^{-}=\min \left\{u_{i j 1}\right\}
\end{aligned}
$$

Calculate the distance of factors from FPIS and FNIS

$$
d=\sqrt{\frac{1}{3}\left(x_{n}^{*}-p_{n}\right)^{2}+\left(y_{n}^{*}-q_{n}\right)^{2}+\left(z_{n}^{*}-r_{n}\right)^{2}} \text { for } \mathrm{n}^{\text {th }} \text { factor and } u_{i j n}=\left(p_{n}, q_{n}, r_{n}\right)
$$

$p, q$, and $r$, are set of values in order for $A^{+}$, where $A^{+}=\left(x_{n}, y_{n}, z_{n}\right)$ and $x, y$, and $z$ are set of values in order.

Similarly, with the same formula we can calculate the value of $d$ for $A^{-}$

$$
\begin{aligned}
& d^{+}=\left\{\sum_{j=1}^{n} d\left(u_{i j}, u_{j}^{+}\right)\right\}, i=\{1,2, \ldots, m\} \\
& d^{-}=\left\{\sum_{j=1}^{n} d\left(u_{i j}, u_{j}^{-}\right)\right\}, i=\{1,2, \ldots, m\}
\end{aligned}
$$

The following equation is to be used to calculate the closeness coefficient of each factor.

$$
C c_{i}=\frac{d^{-}}{d^{-}+d^{+}}, i=\{1,2, \ldots, m\}, C c_{i} \in\{0,1\}
$$

Factors then are ranked by there $C c_{i}$ to the ideal solution in descending order.

\section{Results and Discussion}

\subsection{Weight Calculations-}

In this section, the fuzzy AHP and fuzzy TOPSIS-AHP are used to identify the most impactful factors with the help of weight calculation and analysis on the real input data received from the 50 different experts. The survey form consisted questions on dominance of different factors on one another. Table VII consists of the major factors, which are considered for the analysis and their Fuzzy geometric mean value. The fuzzy geometric mean value is calculated with the procedure 
discussed in fuzzy AHP method and it is used to calculate fuzzy weights, which are written in table VIII.

Table VII: Pairwise comparison for analysis with Fuzzy AHP

\begin{tabular}{cccccc}
\hline Factors & $\begin{array}{c}\text { Environment } \\
\text { Sustainability }\end{array}$ & $\begin{array}{c}\text { Supply \& } \\
\text { Demand }\end{array}$ & Operations & $\begin{array}{c}\text { Port } \\
\text { Selection }\end{array}$ & $\begin{array}{c}\text { Fuzzy } \\
\text { Geometric } \\
\text { Mean Value }\end{array}$ \\
\hline $\begin{array}{c}\text { Environment } \\
\text { Sustainability }\end{array}$ & $(1,1,1)$ & $(6,7,8)$ & $(4,5,6)$ & $(4,5,6)$ & $(3.13,3.63,4.11)$ \\
\hline $\begin{array}{c}\text { Supply and } \\
\text { Demand }\end{array}$ & $\left(\frac{1}{8}, \frac{1}{7}, \frac{1}{6}\right)$ & $(1,1,1)$ & $(2,3,4)$ & $(2,3,4)$ & $(0.84,1.06,1.27)$ \\
\hline Operations & $\left(\frac{1}{6}, \frac{1}{5}, \frac{1}{4}\right)$ & $\left(\frac{1}{4}, \frac{1}{3}, \frac{1}{2}\right)$ & $(1,1,1)$ & $(2,3,4)$ & $(0.53,0.66,0.84)$ \\
\hline Port Selection & $\left(\frac{1}{6}, \frac{1}{5}, \frac{1}{4}\right)$ & $\left(\frac{1}{4}, \frac{1}{3}, \frac{1}{2}\right)$ & $\left(\frac{1}{4}, \frac{1}{3}, \frac{1}{2}\right)$ & $(1,1,1)$ & $(0.31,0.38,0.50)$ \\
\hline
\end{tabular}

Table VIII: Fuzzy geometric mean value and Fuzzy weights

\begin{tabular}{cc}
\hline $\begin{array}{c}\text { Fuzzy Geometric } \\
\text { Mean Value }\end{array}$ & Fuzzy Weight \\
\hline$(3.13,3.63,4.11)$ & $(0.438,0.617,0.822)$ \\
\hline$(0.84,1.06,1.27)$ & $(0.117,0.180,0.254)$ \\
\hline$(0.53,0.66,0.84)$ & $(0.072,0.112,0.168)$ \\
\hline$(0.31,0.38,0.50)$ & $(0.043,0.006,0.100)$ \\
\hline
\end{tabular}

Fuzzy weights are now undergoing deffuzication to give crisp numeric value. The method used for deffuzication is center of area. The weight undergoes normalization to get normalized weight, which are given in the table IX. These are the normalized weights calculated for main factors which can be now ranked.

Table IX: Fuzzy weights and normalized weights

\begin{tabular}{ccc}
\hline Fuzzy Weight & Weight & $\begin{array}{c}\text { Normalized } \\
\text { Weight }\end{array}$ \\
\hline$(0.438,0.617,0.822)$ & 0.625 & 0.641 \\
\hline$(0.117,0.180,0.254)$ & 0.183 & 0.187 \\
\hline$(0.072,0.112,0.168)$ & 0.117 & 0.120 \\
\hline$(0.043,0.006,0.100)$ & 0.049 & 0.052 \\
\hline
\end{tabular}


Similarly, we can calculate the Fuzzy geometric mean value and normalized weights for the subfactors of environmental sustainability, which are shown in Table X and Table XI, respectively. Also, for the sub-factors of supply and demand, which are written in the Table XII and Table XIII, respectively, for the sub-factors of operations, which are written in the Table XIV and Table XV, respectively, and for the sub-factors of port selection, which are written in the Table XVI and Table XVII, respectively. Fuzzy TOPSIS-AHP is another method, which is used to analyze the data shown in Table XVIII.

Table X: Sub-factors for environmental sustainability

\begin{tabular}{ccccc}
\hline Sub-factors & $\begin{array}{c}\text { Adaptation } \\
\text { to climate }\end{array}$ & $\begin{array}{c}\text { Optimized } \\
\text { use of space }\end{array}$ & $\begin{array}{c}\text { Waste } \\
\text { reception } \\
\text { facility }\end{array}$ & $\begin{array}{c}\text { Fuzzy Geometric } \\
\text { Mean Value }\end{array}$ \\
\hline $\begin{array}{c}\text { Adaptation to } \\
\text { climate }\end{array}$ & $(1,1,1)$ & $(1,2,3)$ & $\left(\frac{1}{6}, \frac{1}{5}, \frac{1}{4}\right)$ & $(0.550,0.736,0.908)$ \\
\hline $\begin{array}{c}\text { Optimized use of } \\
\text { space }\end{array}$ & $\left(\frac{1}{3}, \frac{1}{2}, \frac{1}{1}\right)$ & $(1,1,1)$ & $\left(\frac{1}{7}, \frac{1}{6}, \frac{1}{5}\right)$ & $(0.362,0.436,0.584)$ \\
\hline $\begin{array}{c}\text { Waste reception } \\
\text { facility }\end{array}$ & $(4,5,6)$ & $(5,6,7)$ & $(1,1,1)$ & $(2.714,3.107,3.476)$ \\
\hline
\end{tabular}

Table XI: Weights calculated for environmental sustainability

\begin{tabular}{cccc}
\hline $\begin{array}{c}\text { Fuzzy Geometric Mean } \\
\text { Value }\end{array}$ & Fuzzy Weight & Weight & $\begin{array}{c}\text { Normalized } \\
\text { Weight }\end{array}$ \\
\hline$(0.550,0.736,0.908)$ & $(0.151,0.171,0.182)$ & 0.168 & 0.168 \\
\hline$(0.362,0.436,0.584)$ & $(0.099,0.101,0.117)$ & 0.105 & 0.105 \\
\hline$(2.714,3.107,3.476)$ & $(0.746,0.723,0.698)$ & 0.722 & 0.727 \\
\hline
\end{tabular}

Table XII: Sub-factors for supply and demand

\begin{tabular}{cccccc}
\hline $\begin{array}{c}\text { Sub- } \\
\text { factors }\end{array}$ & $\begin{array}{c}\text { World } \\
\text { Economy }\end{array}$ & $\begin{array}{c}\text { Transport } \\
\text { Costs }\end{array}$ & $\begin{array}{c}\text { Merchant } \\
\text { Fleet }\end{array}$ & $\begin{array}{c}\text { Political } \\
\text { Events }\end{array}$ & $\begin{array}{c}\text { Fuzzy Geometric } \\
\text { Mean Value }\end{array}$ \\
\hline $\begin{array}{c}\text { World } \\
\text { Economy }\end{array}$ & $(1,1,1)$ & $(5,6,7)$ & $(3,4,5)$ & $(1,2,3)$ & $(1.967,2.632,3.20)$ \\
\hline $\begin{array}{c}\text { Transport } \\
\text { Costs }\end{array}$ & $\left(\frac{1}{4}, \frac{1}{3}, \frac{1}{2}\right)$ & $(1,1,1)$ & $(6,7,8)$ & $\left(\frac{1}{3}, \frac{1}{2}, \frac{1}{1}\right)$ & $(0.731,0.873,1.12)$ \\
\hline $\begin{array}{c}\text { Merchant } \\
\text { Fleet }\end{array}$ & $\left(\frac{1}{5}, \frac{1}{4}, \frac{1}{3}\right)$ & $\left(\frac{1}{8}, \frac{1}{7}, \frac{1}{6}\right)$ & $(1,1,1)$ & $\left(\frac{1}{4}, \frac{1}{3}, \frac{1}{2}\right)$ & $(0.281,0.330,0.408)$ \\
\hline
\end{tabular}




\begin{tabular}{c}
$\begin{array}{c}\text { Political } \\
\text { Events }\end{array}$ \\
\hline
\end{tabular}$\left(\frac{1}{3}, \frac{1}{2}, \frac{1}{1}\right) \quad(1,2,3) \quad(2,3,4) \quad(1,1,1) \quad(0.903,1.316,1.861)$

Table XIII: Weights calculated for supply and demand

\begin{tabular}{cccc}
\hline $\begin{array}{c}\text { Fuzzy Geometric } \\
\text { Mean Value }\end{array}$ & Fuzzy Weight & Weight & Normalized Weight \\
\hline$(1.967,2.632,3.20)$ & $(0.505,0.508,0.483)$ & 0.498 & 0.575 \\
\hline$(0.731,0.873,1.12)$ & $(0.187,0.1693,0.1692)$ & 0.066 & 0.076 \\
\hline$(0.281,0.330,0.408)$ & $(0.072,0.006,0.061)$ & 0.046 & 0.054 \\
\hline$(0.903,1.316,1.861)$ & $(0.232,0.255,0.281)$ & 0.256 & 0.295 \\
\hline
\end{tabular}

Table XIV: Sub-factors for operations

\begin{tabular}{ccccc}
\hline Sub-factors & $\begin{array}{c}\text { Berth } \\
\text { Scheduling }\end{array}$ & $\begin{array}{c}\text { Cargo prioritization } \\
\text { and terminal } \\
\text { allocation }\end{array}$ & $\begin{array}{c}\text { Crane } \\
\text { allocation }\end{array}$ & $\begin{array}{c}\text { Fuzzy Geometric } \\
\text { Mean Value }\end{array}$ \\
\hline Berth Scheduling & $(1,1,1)$ & $(4,5,6)$ & $(5,6,7)$ & $(2.714,3.107,3.634)$ \\
\hline $\begin{array}{c}\text { Cargo prioritization } \\
\text { and terminal } \\
\text { allocation }\end{array}$ & $\left(\frac{1}{6}, \frac{1}{5}, \frac{1}{4}\right)$ & $(1,1,1)$ & $(2,3,4)$ & $(0.693,0.843,1)$ \\
\hline Crane allocation & $\left(\frac{1}{7}, \frac{1}{6}, \frac{1}{5}\right)$ & $\left(\frac{1}{4}, \frac{1}{3}, \frac{1}{2}\right)$ & $(1,1,1)$ & $(0.329,0.381,0.464)$ \\
\hline
\end{tabular}

Table XV: Weights calculated for operations

\begin{tabular}{cccc}
\hline Fuzzy Geometric Mean Value & Fuzzy Weight & Weight & Normalized Weight \\
\hline$(2.714,3.107,3.634)$ & $(0.724,0.714,0.712)$ & 0.716 & 0.719 \\
\hline$(0.693,0.843,1)$ & $(0.185,0.193,0.196)$ & 0.191 & 0.192 \\
\hline$(0.329,0.381,0.464)$ & $(0.0878,0.0876,0.090)$ & 0.088 & 0.089 \\
\hline
\end{tabular}


Table XVI: Sub-factors for port selection

\begin{tabular}{|c|c|c|c|c|c|c|c|}
\hline Sub-factors & $\begin{array}{c}\text { Port } \\
\text { efficiency }\end{array}$ & $\begin{array}{l}\text { Geographical } \\
\text { locations }\end{array}$ & $\begin{array}{l}\text { Ship visiting } \\
\text { frequency }\end{array}$ & $\begin{array}{c}\text { Port } \\
\text { reputation for } \\
\text { cargo damage }\end{array}$ & $\begin{array}{c}\text { Suitable } \\
\text { infrastructure }\end{array}$ & $\begin{array}{c}\text { Port } \\
\text { charges }\end{array}$ & $\begin{array}{c}\text { Quick } \\
\text { response } \\
\text { to users } \\
\end{array}$ \\
\hline Port efficiency & $(1,1,1)$ & $(1,2,3)$ & $(5,6,7)$ & $(3,4,5)$ & $(1,2,3)$ & $(3,4,5)$ & $(2,3,4)$ \\
\hline $\begin{array}{l}\text { Geographical } \\
\text { locations }\end{array}$ & $\left(\frac{1}{3}, \frac{1}{2}, \frac{1}{1}\right)$ & $(1,1,1)$ & $(4,5,6)$ & $(3,4,5)$ & $(1,2,3)$ & $(2,3,4)$ & $(4,5,6)$ \\
\hline $\begin{array}{l}\text { Ship visiting } \\
\text { frequency }\end{array}$ & $\left(\frac{1}{7}, \frac{1}{6}, \frac{1}{5}\right)$ & $\left(\frac{1}{6}, \frac{1}{5}, \frac{1}{4}\right)$ & $(1,1,1)$ & $(5,6,7)$ & $(4,5,6)$ & $(5,6,7)$ & $(4,5,6)$ \\
\hline $\begin{array}{l}\text { Port reputation } \\
\text { for cargo damage }\end{array}$ & $\left(\frac{1}{5}, \frac{1}{4}, \frac{1}{3}\right)$ & $\left(\frac{1}{5}, \frac{1}{4}, \frac{1}{3}\right)$ & $\left(\frac{1}{7}, \frac{1}{6}, \frac{1}{5}\right)$ & $(1,1,1)$ & $(6,7,8)$ & $(3,4,5)$ & $(9,9,9)$ \\
\hline $\begin{array}{c}\text { Suitable } \\
\text { infrastructure }\end{array}$ & $\left(\frac{1}{3}, \frac{1}{2}, \frac{1}{1}\right)$ & $\left(\frac{1}{3}, \frac{1}{2}, \frac{1}{1}\right)$ & $\left(\frac{1}{6}, \frac{1}{5}, \frac{1}{4}\right)$ & $\left(\frac{1}{8}, \frac{1}{7}, \frac{1}{6}\right)$ & $(1,1,1)$ & $(4,5,6)$ & $(5,6,7)$ \\
\hline Port charges & $\left(\frac{1}{5}, \frac{1}{4}, \frac{1}{3}\right)$ & $\left(\frac{1}{4}, \frac{1}{3}, \frac{1}{2}\right)$ & $\left(\frac{1}{7}, \frac{1}{6}, \frac{1}{5}\right)$ & $\left(\frac{1}{5}, \frac{1}{4}, \frac{1}{3}\right)$ & $\left(\frac{1}{6}, \frac{1}{5}, \frac{1}{4}\right)$ & $(1,1,1)$ & $(1,2,3)$ \\
\hline $\begin{array}{l}\text { Quick response } \\
\text { to users }\end{array}$ & $\left(\frac{1}{4}, \frac{1}{3}, \frac{1}{2}\right)$ & $\left(\frac{1}{6}, \frac{1}{5}, \frac{1}{4}\right)$ & $\left(\frac{1}{6}, \frac{1}{5}, \frac{1}{4}\right)$ & $\left(\frac{1}{9}, \frac{1}{9}, \frac{1}{9}\right)$ & $\left(\frac{1}{7}, \frac{1}{6}, \frac{1}{5}\right)$ & $\left(\frac{1}{3}, \frac{1}{2}, \frac{1}{1}\right)$ & $(1,1,1)$ \\
\hline
\end{tabular}

Table XVII: Weights calculated for port selection

\begin{tabular}{cccc}
\hline Fuzzy Geometric Mean Value & Fuzzy Weight & Weight & Normalized Weight \\
\hline$(1.901,2.737,3.489)$ & $(0.012,0.295,0.299)$ & 0.202 & 0.288 \\
\hline$(1.640,2.258,2.994)$ & $(0.0106,0.243,0.256)$ & 0.169 & 0.242 \\
\hline$(9.523,1.625,1.896)$ & $(0.061,0.175,0.162)$ & 0.132 & 0.188 \\
\hline$(0.989,1.147,1.345)$ & $(0.006,0.123,0.115)$ & 0.081 & 0.116 \\
\hline$(0.644,0.802,1.083)$ & $(0.004,0.085,0.092)$ & 0.060 & 0.086 \\
\hline$(0.303,0.390,0.504)$ & $(0.020,0.042,0.043)$ & 0.035 & 0.05 \\
\hline$(0.232,0.276,0.353)$ & $(0.001,0.029,0.030)$ & 0.021 & 0.03 \\
\hline
\end{tabular}


Table XVIII: Main factors obtained with Fuzzy TOPSIS AHP

\begin{tabular}{cccccc}
\hline Factors & $\begin{array}{c}\text { Environment } \\
\text { Sustainability }\end{array}$ & $\begin{array}{c}\text { Supply \& } \\
\text { Demand }\end{array}$ & Operations & $\begin{array}{c}\text { Port } \\
\text { Selection }\end{array}$ & Weight Cci \\
\hline $\begin{array}{c}\text { Environment } \\
\text { Sustainability }\end{array}$ & $(1,1,1)$ & $(6,7,8)$ & $(4,5,6)$ & $(4,5,6)$ & 0 \\
\hline $\begin{array}{c}\text { Supply and } \\
\text { Demand }\end{array}$ & $\left(\frac{1}{8}, \frac{1}{7}, \frac{1}{6}\right)$ & $(1,1,1)$ & $(2,3,4)$ & $(2,3,4)$ & 0.7629 \\
\hline Operations & $\left(\frac{1}{6}, \frac{1}{5}, \frac{1}{4}\right)$ & $\left(\frac{1}{4}, \frac{1}{3}, \frac{1}{2}\right)$ & $(1,1,1)$ & $(2,3,4)$ & 0.897 \\
\hline Port Selection & $\left(\frac{1}{6}, \frac{1}{5}, \frac{1}{4}\right)$ & $\left(\frac{1}{4}, \frac{1}{3}, \frac{1}{2}\right)$ & $\left(\frac{1}{4}, \frac{1}{3}, \frac{1}{2}\right)$ & $(1,1,1)$ & 0.859 \\
\hline
\end{tabular}

\subsection{Ranking of the Factors}

\subsubsection{Ranking of Factors based on Weights obtained from fuzzy AHP method}

The results obtained from the fuzzy AHP are given in Table XIX, and from this table we can rank the factors and their sub-factors. The opinions of different experts are converted into weight. According to the opinions of different experts and the fuzzy AHP method used for weight calculation, the environmental sustainability achieved first position with weight- 0.641 , followed by supply and demand with weight- 0.187 , operations with weight- 0.120 and the in the last port selection with weight-0.052. Also, the sub-factors of each main factor can be prioritized. In environmental sustainability; the waste reception facility is achieved first priority followed by adoption to climate, and at the last is optimized used space. In supply and demand; the world economy is achieved first priority followed by political events, transport costs, and at the last is merchant fleet. In operations; birth scheduling is on the top of the priority list followed by cargo prioritization and terminal allocation, and at the end crane allocation. In port selection; the port efficiency is obtained at the top of the priority list followed by geographical locations, ship visiting frequency, port reputation for cargo damage, suitable infrastructure, port charges and at the end quick response to users. 
Table XIX: Factor rankings according to fuzzy AHP method

\begin{tabular}{|c|c|c|c|c|c|}
\hline Factor & Weight & Rank & Sub-factor & Weight & Rank \\
\hline \multirow{3}{*}{$\begin{array}{l}\text { Environment } \\
\text { Sustainability }\end{array}$} & \multirow{3}{*}{0.641} & \multirow{3}{*}{1} & Adaptation to climate & 0.168 & 2 \\
\hline & & & Optimized use of space & 0.105 & 3 \\
\hline & & & Waste reception facility & 0.727 & 1 \\
\hline \multirow{4}{*}{$\begin{array}{l}\text { Supply and } \\
\text { Demand }\end{array}$} & \multirow{4}{*}{0.187} & \multirow{4}{*}{2} & World Economy & 0.575 & 1 \\
\hline & & & Transport Costs & 0.076 & 3 \\
\hline & & & Merchant Fleet & 0.054 & 4 \\
\hline & & & Political Events & 0.295 & 2 \\
\hline \multirow{3}{*}{ Operations } & \multirow{3}{*}{0.120} & \multirow{3}{*}{3} & Berth Scheduling & 0.719 & 1 \\
\hline & & & $\begin{array}{l}\text { Cargo prioritization and terminal } \\
\text { allocation }\end{array}$ & 0.192 & 2 \\
\hline & & & Crane allocation & 0.089 & 3 \\
\hline \multirow{7}{*}{$\begin{array}{c}\text { Port } \\
\text { Selection }\end{array}$} & \multirow{7}{*}{0.052} & \multirow{7}{*}{4} & Port efficiency & 0.288 & 1 \\
\hline & & & Geographical locations & 0.242 & 2 \\
\hline & & & Ship visiting frequency & 0.188 & 3 \\
\hline & & & Port reputation for cargo damage & 0.116 & 4 \\
\hline & & & Suitable infrastructure & 0.086 & 5 \\
\hline & & & Port charges & 0.05 & 6 \\
\hline & & & Quick response to users & 0.03 & 7 \\
\hline
\end{tabular}

The fuzzy AHP ranking is used to prioritize the factors according to the way researchers are expecting. If to give the importance of these factors according to their rank by the researchers in order to do some improvement that can give better results in maritime logistics.

\subsubsection{Ranking of Factors based on Weights obtained from fuzzy TOPSIS-AHP method}

The results obtained from the fuzzy TOPSIS AHP are given in Table XX. The opinions of different experts are converted into weight. According to the opinions of different experts and the fuzzy TOPSIS AHP method used for weight calculation, operations achieved the first position with weight- 0.897 , followed by port selection with weight- 859 , supply and demand with weight07629 , and at the last environment sustainability with weight- 0 .

Table XX: The ranking from Fuzzy TOPSIS-AHP method

\begin{tabular}{ccc}
\hline Factors & Weight Cc & Rank \\
\hline Environment Sustainability & 0 & 4 \\
\hline Supply and Demand & 0.7629 & 3 \\
\hline Operations & 0.897 & 1 \\
\hline Port Selection & 0.859 & 2 \\
\hline
\end{tabular}




\subsubsection{Comparison between fuzzy AHP and fuzzy TOPSIS-AHP results}

When the results were compared from fuzzy AHP and fuzzy TOPSIS-AHP, it shows contrasting results. The $1^{\text {st }}$ rank is environmental sustainability when weight obtained from fuzzy AHP while it is in the last when weight obtained from fuzzy TOPSIS AHP. $1^{\text {st }}$ rank is operations when weight obtained from fuzzy TOPSIS AHP while it is in the third position when weight obtained from fuzzy AHP

\subsection{Managerial insights}

This study provides some managerial insights in order to rank the factors affecting the shipping logistics industries. The rank and prioritization of factors withdraw the attention of researchers, logistics managers, and decision-makers to enhance the performance of the Indian shipping logistics industries. The expert's opinions which are converted into the weight and the weight of each factor are calculated by fuzzy AHP and fuzzy TOPSIS-AHP, which helps in choosing the important factors associated with the shipping logistics industries. This study's results may help to decide the better selection of impactful factors for shipping logistics sector.

\section{Conclusions}

In this study, we have focused to rank and prioritize the considered factors associated with the shipping logistics to make the efficient shipping logistics system. We have proposed a new hybrid MCDM method i.e., fuzzy TOPSIS-AHP, which is developed by hybridization of two MCDM methods that are fuzzy AHP and fuzzy TOPSIS. Two MCDM methods are used to calculate the weights required for ranking and prioritization of the factors. First, the ranking of factors is obtained with help of the fuzzy AHP method and then by using the new proposed hybrid fuzzy TOPSIS-AHP method.

The rank of factors with the help of fuzzy AHP method is; environment sustainability is in the top followed by supply and demand, operations and lastly port selection, while with the help of new proposed hybrid fuzzy TOPSIS AHP method is; operations is in the top followed by port selection, supply and demand, and lastly environment sustainability. In the future, this work could be improved by applying some other MCDM techniques in order to rank and prioritize the factors. 


\section{Declarations}

- Ethics approval and consent to participate- Not applicable

- Include a statement on ethics approval and consent (even where the need for approval was waived)- Not applicable

- Include the name of the ethics committee that approved the study and the committee's reference number if appropriate- Not applicable

- Consent for publication- Not applicable

- Availability of data and material- Code available in MS Excel

- Funding- No funding applicable for this research.

- Competing interests- The authors declare that they have no competing interests.

- Authors' contributions- All authors were involved in the entire research work. All authors read and approved the final manuscript.

- Acknowledgements- Authors thank anonymous reviewers for their constructive comments.

\section{References}

Acciaro, M., Vanelslander, T., Sys, C., Ferrari, C., Roumboutsos, A., Giuliano, G., ... Kapros, S. (2014a). Environmental sustainability in seaports: a framework for successful innovation. Maritime Policy and Management, 480-500. https://doi.org/10.1080/03088839.2014.932926

Acciaro, M., Vanelslander, T., Sys, C., Ferrari, C., Roumboutsos, A., Giuliano, G., ... Kapros, S. (2014b). Environmental sustainability in seaports: a framework for successful innovation. Maritime Policy and Management, 41(5), 480-500. https://doi.org/10.1080/03088839.2014.932926

Chen, C. T. (2000). Extensions of the TOPSIS for group decision-making under fuzzy environment -( Vertex method - full formulars -do exel file). Fuzzy Sets and Systems, 114(1), 1-9. https://doi.org/10.1016/S0165-0114(97)00377-1

Corbett, J. J., \& Winebrake, J. (2008). The Impacts of Globalisation on International Maritime 
Transport Activity. Springer Science \& Business Media, (November), 31pp.

D'este, G. M., \& Meyrick, S. (1992). Carrier selection in a RO/RO ferry trade part 1. Decision factors and attitudes. Maritime Policy and Management, 19(2), 115-126. https://doi.org/10.1080/03088839200000019

Daganzo, C. F. (1989). The crane scheduling problem. Transportation Research Part B, 23(3), 159-175. https://doi.org/10.1016/0191-2615(89)90001-5

Daultani, Y., Goswami, M., Vaidya, O. S., \& Kumar, S. (2019). Inclusive risk modeling for manufacturing firms: a Bayesian network approach. Journal of Intelligent Manufacturing, 30(8), 2789-2803.

De, A., Mogale, D. G., Zhang, M., Pratap, S., Kumar, S. K., \& Huang, G. Q. (2019). Multi-period multi-echelon inventory transportation problem considering stakeholders behavioural tendencies. International Journal of Production Economics, 107566.

Ducruet, C., \& Lugo, I. (2013). Cities and transport networks in shipping and logistics research. Asian Journal of Shipping and Logistics, 29(2), 145-166. https://doi.org/10.1016/j.ajs1.2013.08.002

Gupta, E. V., Mogale, D. G., \& Tiwari, M. K. (2019). Optimal Control of Production and Maintenance Operations in Smart Custom Manufacturing Systems with Multiple Machines. IFAC-PapersOnLine, 52(13), 241-246.

Hoffmann, J., \& Change, T. (2014). Globalisation: The maritime nexus. (May).

Hsieh, T. Y., Lu, S. T., \& Tzeng, G. H. (2004). Fuzzy MCDM approach for planning and design tenders selection in public office buildings. International Journal of Project Management, 22(7), 573-584. https://doi.org/10.1016/j.ijproman.2004.01.002

Jugović, A., Komadina, N., \& Hadžić, A. P. (2015). Scientific Journal of Maritime Research. Factors Influencing the Formation of Freight Rates on Maritime Shipping Markets, 29, 2329.

Kim, K. H., \& Moon, K. C. (2003). Berth scheduling by simulated annealing. Transportation Research Part B: Methodological, 37(6), 541-560. https://doi.org/10.1016/S01912615(02)00027-9

Le, T. V., Stathopoulos, A., Van Woensel, T., \& Ukkusuri, S. V. (2019). Supply, demand, operations, and management of crowd-shipping services: A review and empirical evidence. Transportation Research Part C: Emerging Technologies, 103(March), 83-103. https://doi.org/10.1016/j.trc.2019.03.023

McGinnis, L. M. (1979). Maternal Separation Vs Removal Prom Group Companions in Rhesus 
Monkeys. Journal of Child Psychology and Psychiatry, 20(1), 15-27. https://doi.org/10.1111/j.1469-7610.1979.tb01703.x

Meena, S. R., Meena, S. D., Pratap, S., Patidar, R., \& Daultani, Y. (2019). Strategic analysis of the Indian agri-food supply chain. Opsearch, 56(3), 965-982. https://doi.org/10.1007/s12597019-00380-5

Mogale, D. G., Lahoti, G., Jha, S. B., Shukla, M., Kamath, N., \& Tiwari, M. K. (2018). Dual market facility network design under bounded rationality. Algorithms, 11(4), 54.

Mogale, D. G., Ghadge, A., Kumar, S. K., \& Tiwari, M. K. (2019a). Modelling supply chain network for procurement of food grains in India. International Journal of Production Research, 1-20.

Mogale, D. G., Cheikhrouhou, N., \& Tiwari, M. K. (2019b). Modelling of sustainable food grain supply chain distribution system: a bi-objective approach. International Journal of Production Research, 1-24.

Pham, H. C., Nguyen, T. T., Mcdonald, S., \& Tran-Kieu, N. Q. (2019). Information Sharing in Logistics Firms: An Exploratory Study of theVietnamese Logistics Sector. Asian Journal of Shipping and Logistics, 35(2), 87-95. https://doi.org/10.1016/j.ajs1.2019.06.001

Pratap, S., Daultani, Y., Tiwari, M. K., \& Mahanty, B. (2018). Rule based optimization for a bulk handling port operations. Journal of Intelligent manufacturing, 29(2), 287-311.

Psaraftis, H. N. (2016). Green Maritime Logistics: The Quest for Win-win Solutions. Transportation Research Procedia, 14, 133-142. https://doi.org/10.1016/j.trpro.2016.05.049

Rødseth, K. L., Wangsness, P. B., \& Schøyen, H. (2018). How do economies of density in container handling operations affect ships' time and emissions in port? Evidence from Norwegian container terminals. Transportation Research Part D: Transport and Environment, 59, 385-399. https://doi.org/10.1016/j.trd.2017.12.015

Saaty, T. L. (1990). How to Make a Decision: Advice for Scientists. European Journal of Operational Research, Vol. 48, pp. 9-26.

Sayareh, J., \& Alizmini, H. R. (2014). A hybrid decision-making model for selecting container seaport in the persian gulf. Asian Journal of Shipping and Logistics, 30(1), 75-95. https://doi.org/10.1016/j.ajsl.2014.04.004

Seo, Y. J., Ha, M. H., Yang, Z., \& Bhattacharya, S. (2018). The Ship Management Firm Selection: The Case of South Korea. Asian Journal of Shipping and Logistics, 34(3), 258-268. https://doi.org/10.1016/j.ajsl.2018.09.008

Singh, S. H., Maiyar, L. M., \& Bhowmick, B. (2020). Assessing the appropriate grassroots 
technological innovation for sustainable development. Technology Analysis \& Strategic Management, 32(2), 175-194.

Sirisawat, P., \& Kiatcharoenpol, T. (2018). Fuzzy AHP-TOPSIS approaches to prioritizing solutions for reverse logistics barriers. Computers and Industrial Engineering, 117(April 2017), 303-318. https://doi.org/10.1016/j.cie.2018.01.015

Tong, J., \& Nachtmann, H. (2017). Cargo prioritization and terminal allocation problem for inland waterway disruptions oa. Maritime Economics and Logistics, 19(3), 403-427. https://doi.org/10.1057/mel.2015.34

Trishala, S. (2016). Insights Into the Indian Maritime Industry and Ports in. 1-26.

Ugboma, C., Ugboma, O., \& Ogwude, I. C. (2006). An Analytic Hierarchy Process (AHP) Approach to Port Selection Decisions - Empirical Evidence from Nigerian Ports. Maritime Economics and Logistics, 8(3), 251-266. https://doi.org/10.1057/palgrave.mel.9100160

Ursavas, E. (2017). Crane allocation with stability considerations oa. Maritime Economics and Logistics, 19(2), 379-401. https://doi.org/10.1057/mel.2015.35

Venkita Subramanian, K., \& Thill, J. C. (2019). Effect of privatization and inland infrastructural development on India's container port selection dynamics. Asian Journal of Shipping and Logistics, 35(4), 220-229. https://doi.org/10.1016/j.ajsl.2019.12.009

Zeng, Q., Feng, Y., \& Chen, Z. (2017). Optimizing berth allocation and storage space in direct transshipment operations at container terminals oa. Maritime Economics and Logistics, 19(3), 474-503. https://doi.org/10.1057/mel.2016.2 